\title{
The Effect of an Elective Algebra Teaching Course on Prospective Mathematics Teachers' Pedagogical Content Knowledge
}

\author{
Mustafa Guler ${ }^{1 *} \mathbb{D}$, Derya Celik ${ }^{1}$ (D) \\ ${ }^{1}$ Trabzon University, Fatih Faculty of Education, Department of Mathematics Education, TURKEY \\ *Corresponding Author: mustafaguler@trabzon.edu.tr
}

Citation: Guler, M., \& Celik, D. (2021). The Effect of an Elective Algebra Teaching Course on Prospective Mathematics Teachers' Pedagogical Content Knowledge. International Electronic Journal of Mathematics Education, 16(2), em0636. https://doi.org/10.29333/iejme/10902

\begin{abstract}
ARTICLE INFO
Received: 6 Oct. 2020

Accepted: 23 Mar. 2021

ABSTRACT

Effective teachers have knowledge not only of the subject they are teaching, but also of how to teach it appropriately. To develop these aspects of knowledge, faculties of education include a number of courses that address the related skills. From the perspective of mathematics teacher education, courses related to mathematics teaching have come to the forefront in recent years. The current study, in particular, attempted to test whether prospective elementary mathematics teachers' (PEMTs) pedagogical content knowledge (PCK) in the domain of algebra improved through attendance in a structured elective course. The study was conducted according to a comparison group research design with 155 prospective teachers. The data collection tool consisted of a 20-question algebra pedagogical content knowledge (APCK) test developed by the researchers in consideration of the knowledge for algebra teaching framework of Ferrini-Mundy and colleagues (2005). The results indicated that the PEMTs who took the algebra teaching course performed better than their peers, with statistically significant differences in the various components of algebra teaching knowledge. Given the findings, some implications for mathematics teacher educators are discussed.
\end{abstract}

Keywords: pedagogical content knowledge, knowledge for algebra teaching, professional development, prospective mathematics teachers

\section{INTRODUCTION}

Teacher quality is now recognized as one of the most important factors in student achievement (Blömeke et al., 2016; Hattie, 2009). One of the first concerns that comes to mind in this regard is professional knowledge. Although the literature relating to teacher education in general and to the professional knowledge types that teachers should possess in particular is fairly recent, many studies have been conducted in the last three decades since Shulman (1986) introduced his domains of knowledge framework. Among these were studies conducted specifically to identify knowledge components in areas such as mathematics education (e.g., Ball et al., 2008).

Professional knowledge, and teacher knowledge in particular, is often identified according to three domains (Baki, 2018; Grossmann \& Richert, 1988; Shulman, 1986, 1987): content knowledge (CK), pedagogical content knowledge (PCK), and general pedagogical knowledge (GPK). However, according to König et al. (2011), despite an increase in studies on teacher education, the exact nature of GPK and what this knowledge domain comprises have still not been precisely defined. Moreover, in the context of Turkey, the courses in all teacher training programs related to GPK are standardized and are not specific to a particular field. Therefore, the studies carried out with in-service or pre-service teacher education programs are primarily focused on either CK or PCK (e.g., Güler \& Çelik, 2019; Krauss et al., 2008; Sintema \& Marbán, 2020; Tatto et al., 2008).

In this regard, there is a consensus that in order for teachers to be effective, they should have knowledge not only of the subject they are teaching, but also of the appropriate ways to teach it (Kula-Ünver, 2020; Manizade \& Mason, 2011; Tanışlı et al., 2020). As such, the concepts of CK and PCK have been viewed as prominent among the necessary knowledge components for teacher. In the 1990s, for example, when the concepts of CK and PCK began to gain interest, the majority of the studies carried out in this area aimed to measure knowledge about a concept or subject (e.g., Even, 1993; Fuller, 1996). This approach continued in the 2000s, where in the past decade, in particular, CK and PCK were examined in either a single content domain (e.g., McCrory et al., 2012) or multiple domains (Blömeke et al., 2011; Tatto et al., 2008) in order to compare teacher education programs in different countries. Such comparative studies have allowed countries around the world to evaluate the current status of their teacher education systems in comparison with one another.

A variety of techniques have been applied for measuring the professional knowledge of teachers, depending on the purpose of a study and the available facilities. For example, if a researcher wants to examine the CK or PCK of a limited number of teachers 
or prospective teachers from certain perspectives, direct observation of their teaching activities may be preferred (Park et al., 2011; Taylan \& da Ponte, 2016). On the other hand, a survey method may be more appropriate for studies aiming to present the current situation with a large group of participants (Çelik et al., 2016; Tatto et al, 2012). For example, in a study in which we adopted latter approach in 2014, we measured the PCK of prospective elementary mathematics teachers (PEMTs) in the domain of algebra learning and found noteworthy deficiencies (see Çelik \& Güler, 2018). The present study, which is a continuation of the related study in which these deficiencies were identified, aims to examine the impact of an elective course included in the teacher education program of a state university in overcoming the difficulties experienced by PEMTs.

\section{Algebra and Algebra Teaching}

Algebra, which is taught implicitly in primary school but is included explicitly in the curriculum beginning in middle school, constitutes the basis for secondary school and university mathematics. Regarded as a general form of mathematical language (Usiskin, 1988), algebra is considered as a gateway to abstract thinking (Witzel et al., 2003). Furthermore, considering that mathematics is by nature abstract, it can be asserted that algebra is at the heart of mathematics teaching. This function of mathematics has been a primary contention of those who argue that algebra should be more dominant in the curriculum (National Council of Teachers of Mathematics [NCTM], 2000). However, regardless of these views regarding the role of algebra and movements for improvement of education programs, a solution has yet to be reached to address both the algebra performance of students and the APCK of prospective teachers.

With respect to results of the Trends in International Mathematics and Science Study (TIMSS), it can be seen that students experience difficulties in the field of algebra in many countries (Bütüner \& Güler, 2017). Similarly, the results of the TEDS-M project conducted in numerous countries revealed substandard levels of APCK in mathematics teacher candidates (Tatto et al., 2012). Another project carried out with 1367 Turkish prospective mathematics teachers examined their CK and PCK and revealed that the field in which the participants performed least effectively was algebra (Çelik et al., 2016). Finally, another study, some of the participants of which were also involved in the present study, focused specifically on the algebra content domain. The researcher found that the prospective teachers had significant difficulties in PCK in terms of algebra (Güler, 2014).

As with all teacher education programs, elementary mathematics teacher education is standardized for Turkish universities that adopt the content of the Council of Higher Education. The course content of all teacher education programs comprises $50 \%$ content knowledge and pedagogical content knowledge; 30\% professional knowledge of teaching; and 20\% general culture knowledge (Council of Higher Education [CHE], 2007). In addition, each faculty of education are also authorized to create elective courses for teacher trainees, in line with the Bologna Process of 2014 (see European Commission, 2015). In consideration of the problems encountered by the PEMTs, as well as the Council's decision to permit faculties of education to establish elective courses, the researchers, as academics and members of a university faculty of education, decided to design and offer an elective course to address these issues. Our proposal for the Algebra Teaching course was accepted as an elective course, but then adopted as compulsory content to be taught in the final semester of the program previously. The content of this course had not been taught separately; rather, it was addressed in the context of a Specialized Teaching Methods course and a Program Development course. The new course was officially added to the teaching program at our university for students who enrolled in the 2014-2015 academic year. The course was taught for the first time at our university as a separate offering in the 7th semester of the 2017-2018 academic year. In the program created by the Council of Higher Education, this course was decided to be taught as compulsory content in all teacher education programs in Turkey. In this context, the results of the present study feature a content proposal for a course to be taught in all universities in the 2021-2022 academic year.

\section{Knowledge of Algebra for Teaching}

To determine the knowledge bases required for effective algebra teaching, Ferrini-Mundy and her colleagues conducted a project known as Knowledge of Algebra for Teaching (KAT). Two important outcomes of her work are a theoretical framework that characterizes knowledge for teaching school algebra (Ferrini-Mundy et al., 2005) and a road map for the development of questions (items) for measuring knowledge for teaching algebra. This theoretical framework was then adapted through different studies, as illustrated in Figure 1.

The framework in Figure 1 identifies the components of knowledge for teaching algebra. The preparation of questions representing each element involves the assumption that the knowledge of algebra teaching will be measured accordingly. The CK and PCK components are represented by the X-axis, which indicates algebra knowledge for teaching. Accordingly, CK is represented by $A$, while $B$ and $C$ correspond to the two components of PCK. On the other hand, the domains of mathematical knowledge are shown on the Z-axis, including algebraic concepts as a content domain. These domains are "core concepts and procedures", "algebraic representations", "applications", and "reasoning and proof". Moreover, within the algebra content shown on the $Y$ axis, the subjects to be measured are stated. The components which are focused on in this study are based on the definitions given in Figure 1. In this regard, the study focused on the components of algebra pedagogical content knowledge (APCK) relating to knowledge of learner and presentation of content. Content knowledge was not examined in the study.

In summary, the present study examines the PCK of PEMTs in algebra who were educated in two different cohorts. In the first cohort, the prospective teachers did not take any courses that addressed algebra teaching in particular, but they studied algebra teaching content in courses such as Specialized Teaching Methods and Mathematics Curriculum. The main purpose of this study was to examine the effectiveness of the Algebra Teaching course taught with the second cohort in terms of addressing the difficulties experienced by the prospective teachers in APCK from the first cohort. 


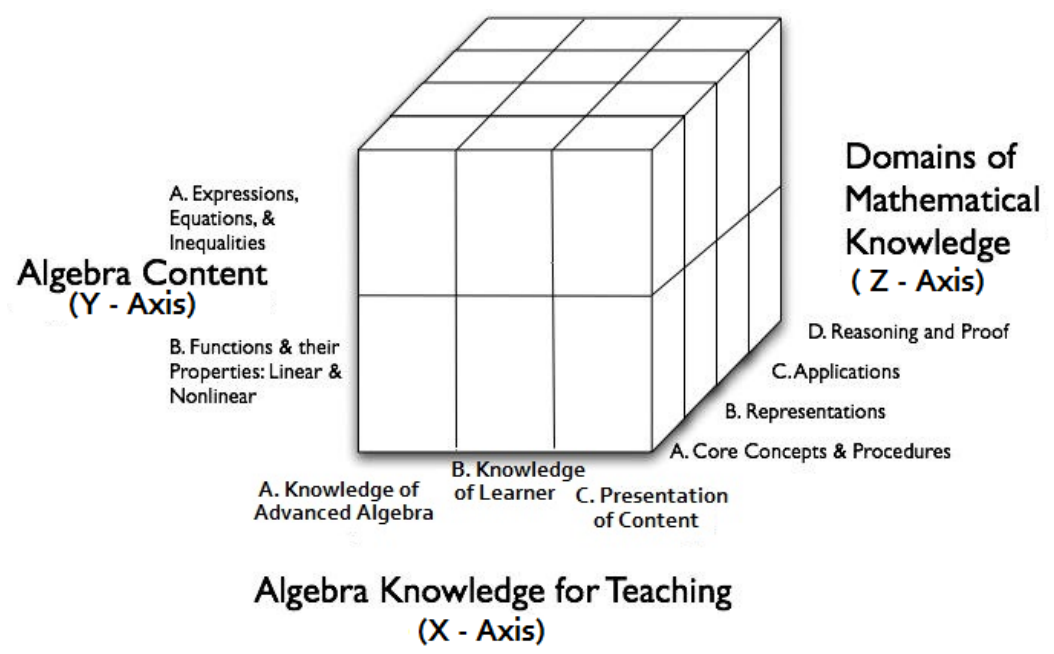

Figure 1. Adapted framework for evaluating knowledge for teaching algebra (Güler \& Çelik, 2018)

Table 1. Courses taught in elementary mathematics teacher education programs

\begin{tabular}{|c|c|}
\hline Course Types & Course name \\
\hline $\begin{array}{l}\text { Major area } \\
\text { courses }\end{array}$ & $\begin{array}{l}\text { Abstract Mathematics I and II, Basic Physics, Introduction to Algebra, Physics I and II, Analysis I, II and III, Linear Algebra I and } \\
\text { II, Analytical Geometry I and II, Statistics, Probability, Differential Equations, Theory of Numbers. }\end{array}$ \\
\hline $\begin{array}{l}\text { Specialized } \\
\text { courses }\end{array}$ & $\begin{array}{l}\text { Instructional Technology and Materials Design, Specialized Teaching Methods I and II, Assessment and Evaluation in ME, } \\
\text { Program Development in ME, School Practice, School Experience, History of Mathematics, Special Education in ME, } \\
\text { Computer Supported Instruction in ME. }\end{array}$ \\
\hline \multicolumn{2}{|c|}{ Pedagogy courses Introduction to Educational Sciences, Psychology of Education, Teaching Principles and Methods, Classroom Man } \\
\hline $\begin{array}{l}\text { Liberal education } \\
\text { courses }\end{array}$ & $\begin{array}{l}\text { Turkish I and II, English I and II, History of Ataturk's Principles and Reforms I and II, Information and Communication } \\
\text { Technologies, History of Science, History of Turkish Education. }\end{array}$ \\
\hline *Elective courses & $\begin{array}{l}\text { Environmental Education, Mathematics and Life, Field Research in ME, Creative Drama, Problem Solving in Mathematics, } \\
\text { Contemporary Approaches in ME, Science, Technology and Society, Graphic Analysis, Algebra Teaching* }{ }^{\star} \text { Parent Education*, } \\
\text { Media Literacy*. }\end{array}$ \\
\hline
\end{tabular}

\section{METHOD}

In this study, the researchers examined the impact of course content that was specifically designed to alleviate the difficulties of PEMTs in the algebra content domain in the context of PCK. Accordingly, comparison group design method (Shaughnessy et al., 2009) was employed. The study was conducted at a state university in the north of Turkey. The data were collected from two different cohorts. The first cohort had graduated in 2013, and the data were collected during their final semester of study. The data from the second cohort were gathered immediately prior to their graduation in 2018 , as the first generation of students were taught according to the new approach with respect to algebra teaching.

\section{Participants}

A total of 155 prospective teachers who were enrolled in their final year of an Elementary Mathematics Teaching program at a public university participated in the study. These included 101 PEMTs in the final semester of 2013 and 54 PEMTs in the final semester of 2018. In 2013, 101 out of 120 (78 female and 23 male) students volunteered to participate, while in 2018, 54 out of 80 students (42 female and 12 male) agreed to take part. The difference in numbers between the two cohorts was due to a reduction in the university quotas for teaching programs by the Council of Higher Education. For each cohort, the courses related to mathematics, mathematics education, general pedagogy and general culture were exactly the same. The only difference in the coursework encountered by the two cohorts was the elective courses; and the only difference in the elective courses in terms of mathematics education was the Algebra Teaching course taught with the second cohort. The other elective courses did not involve either mathematics or mathematics education but consisted of general culture courses that were taken jointly by students in various university programs.

\section{Process}

In Turkey, the courses to be taught in teacher education are mostly determined by the Council of Higher Education, although steps have been taken regarding devolution of authority from the center to the education faculties. However, in accordance with the approach of the Bologna Process of 2014, university education faculties were given the authority to develop the content of certain elective courses. Major area courses, specialized courses, pedagogy courses and liberal education courses have primarily remained the same after 2014. The courses taught in elementary mathematics teaching programs are outlined in Table 1. 
Table 2. Objectives and content of the Algebra Teaching course

\section{Objectives}

- To be able to provide appropriate instructional explanations for teaching arithmetic generalizations, shape and number patterns and to use appropriate methods and techniques.

- To explain the concept of variables and types of variables and to make appropriate instructional explanations and use appropriate methods and techniques for teaching these concepts.

- To provide appropriate instructional explanations for the teaching of algebraic expressions and to use appropriate methods and techniques.

- To make appropriate instructional explanations and use appropriate methods and techniques for teaching algebraic verbal problems.

- To make appropriate instructional explanations and to use appropriate patterns, problems, methods and techniques to improve functional thinking.

Table 3. Algebra teaching course content by weeks

\begin{tabular}{ccc}
\hline Weeks & Focused Concepts & Specialized Focus \\
\hline Week -1 & Introduction to algebra and algebra teaching & $\begin{array}{c}\text { What is algebra, what are the main aims of algebra teaching, } \\
\text { addressing the basic problems encountered in algebra teaching }\end{array}$ \\
\hline Week -2 & $\begin{array}{c}\text { Analysis of the acquisitions in algebra content domain in the } \\
\text { curriculum }\end{array}$ & $\begin{array}{c}\text { Examination of middle school mathematics curriculum of the } \\
\text { algebra content domain acquisitions with a developmental } \\
\text { perspective }\end{array}$ \\
\hline
\end{tabular}

\begin{tabular}{lc}
\hline Week $3-4$ & Letter symbols and their meanings \\
\hline Week $5-6$ & Algebraic expressions and operations in algebraic expressions \\
\hline Week -7 & Equity \\
\hline Week $8-9$ & Equation \\
\hline Week 10 & Inequalities \\
\hline Week 11 & Patterns \\
\hline Week $12-14$ & Linear functions and their graphs \\
\hline
\end{tabular}

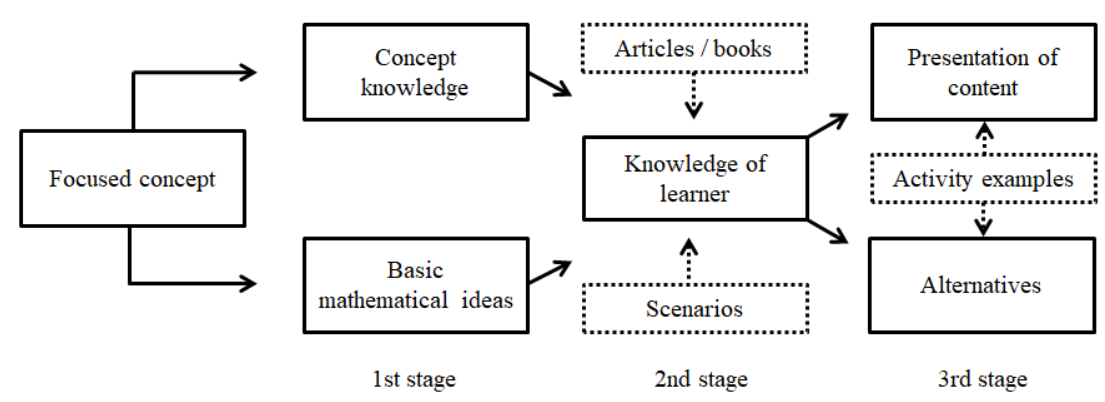

Figure 2. Teaching process of how to teach algebraic concepts

The PEMTs in the first cohort took courses in Introduction to Algebra and Linear Algebra I and II as major area courses related to algebra, but they did not take specialized courses in algebra teaching. Instead, they received instruction in general methods and techniques for teaching algebra through courses such as Specialized Teaching Methods I and II. In addition, the place and order of the algebra-related objectives taught in the Turkish Middle School Curriculum were addressed in the Program Development Course. In these courses, other learning domains such as numbers, geometry and data were also taught. For the second cohort, instruction in algebra teaching was applied differently from the first cohort, offering PEMTs the opportunity to focus directly on the teaching of algebraic concepts. Table 2 shows the main objectives of the Algebra Teaching course.

A developmental approach was adopted to address the objectives presented in Table 2. Accordingly, a hierarchical relationship between concepts was established by examining the algebra outcomes outlined in the curriculum. In this context, the process began with examining the definition of algebra and its aims, as well as the objectives in the curriculum. Afterwards, the concepts covered in the course were addressed week by week. The 14-week content is presented in Table 3.

As Table 3 indicates, the first two weeks of the program served as an introduction to algebra teaching; while in the following weeks, fundamental concepts, from letter symbols and their meanings to functions, were discussed. Although functions were not included in the curriculum as a direct outcome, they were addressed in the content, because they are related to linear equations and graphs, which are taught in the eighth grade. The process of teaching how to teach with respect to these concepts, addressed in the final 11 weeks of the semester, is shown in Figure 2.

An important part of the course content provided in the mathematics curriculum consists of basic algebra concepts. A threestage approach was followed in addressing these concepts in order to develop the PEMTs' mathematics teaching knowledge: (1) knowledge of concepts and basic mathematical ideas related to content knowledge, (2) knowledge of the learner, and (3) specialized teaching methods and techniques, as emphasized in many theoretical frameworks (e.g., Ball et al., 2008). In the first stage, while introducing a concept, a discussion was held by the lecturer concerning what we already know about it and the basic mathematical ideas that we should pass on to students. In discussing the nature of the concept, we also focused on why it should be taught. Afterward, in the second stage, the PEMTs were given readings from scientific articles or books to inform them about learners' understanding of the concept. In some cases, the questions used in scientific studies that aimed to define challenges or 


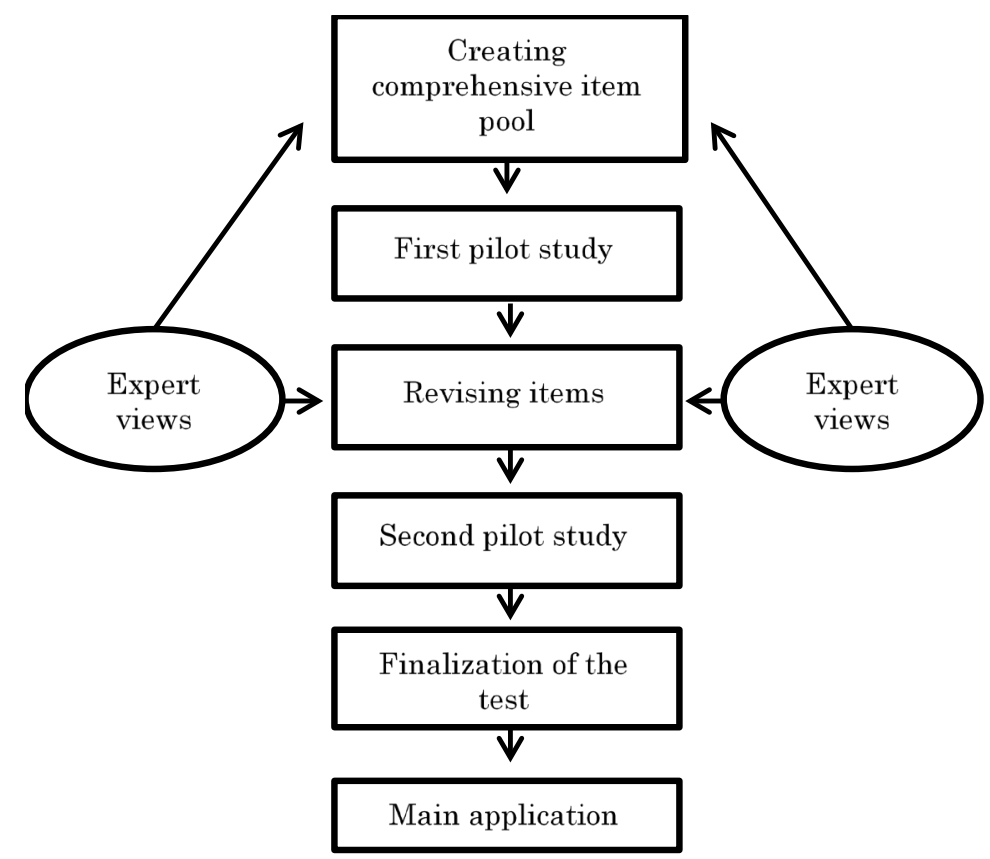

Figure 3. Development process of the test

misconceptions faced by learners were first given to the prospective teachers, and they were asked to come up with solutions. Afterward, a discussion environment was provided in consideration of their responses, guided by questions such as, "What kind of answers might students give to this question? What misconceptions might they have?" Additionally, scenario-type questions were asked in order to prompt the PEMTs to focus on what learners might be thinking in a given situation. Finally, the participants were assigned to groups of three to four and provided with sample activities that could be used in the teaching of the related concept. They were asked to critique these in terms of the presentation of the content and to provide alternative suggestions for the improvement.

\section{Instrument}

In order to measure the algebra teaching knowledge of the PEMTs, an APCK test was used as a data collection tool. The test included three different types of questions: multiple choice, complex multiple choice, and open-ended. The theoretical framework illustrated in Figure 1 was taken into consideration in developing the test, with test items designed to cover each part. The development process is presented briefly in Figure 3.

In developing the APCK item pool, the researchers considered the projects carried out to measure teachers' CK and PCKs (TEDS-M, COACTIV, etc.), as well as the misconceptions of students about algebra cited in the literature. The APCK test questions were designed in accordance with the Turkish middle school mathematics curriculum, and they did not require a high level of pure algebra knowledge due to the nature of the PCK items. The content validity of the items was confirmed by via feedback given by five experts in mathematics education. Next, an initial pilot study was applied with one group of students to test the comprehensibility of the items, and then, following revision based on the results, a second pilot study was conducted with a second group independent from the main study. A reliability analysis was then performed via Rasch analysis to determine whether the compatibility values and discriminations of the items were suitable for the model. A detailed presentation of the validity and reliability analysis was presented in Güler and Çelik (2018). According to the reliability analysis results, the individual reliability for the APCK test, which provides a value close to the overall test reliability coefficient, was between .81 and .83 (for sample items, see Güler \& Çelik, 2018, p. 194).

\section{Data Collection and Analysis}

In consideration of the results of the pilot studies and the feedback from the experts, the PEMTs in both cohorts were given 60 minutes to complete the test items. The test was administered using two different booklets in which the questions were arranged differently in order to minimize the effects of the participants on each other during the application. When scoring the tests, the responses were scored as 0 or 1 for the multiple-choice and short answer items, while a maximum of 2 points were assigned for some of the open-ended items. As an example, Table 4 represents the analytic scoring rubric for the $10^{\text {th }}$ item of the APCK test.

To determine whether statistically significant differences exist between the performances of the PEMTs in each of the cohorts, comparison tests were performed to the datasets in the $\mathrm{X}, \mathrm{Y}$ and $\mathrm{Z}$ axes of Figure 1 . Before these tests were conducted, some assumptions were tested. First, normality tests were conducted to see whether the data were normally distributed. In addition, skewness and kurtosis values, and plots were also checked. Second, Levene's test was performed to check if the variances were equal for both cohorts. As a result, Shapiro-Wilks tests revealed normality ( $p>0.05)$ for all the data sets. In addition, because the coefficients of skewness and kurtosis values were found between -1 to +1 , it was inferred that the distributions did not differ significantly from the normal distribution (George \& Mallery, 2016). On the other hand, the significant values found for Levene's test were smaller than .05 except for the "representations" variable. Thus, the reports except this variable were presented based 
Table 4. Scoring rubric of $10^{\text {th }}$ item in APCK test

\begin{tabular}{ccc}
\hline $\mathbf{1 0}^{\text {th }}$ question & Score & Rationale \\
\hline $\begin{array}{c}\text { The teacher writes the following inequality on the blackboard and } \\
\text { asks her students to find a solution. } \\
-\boldsymbol{x}<\mathbf{7}\end{array}$ & 2 & $\begin{array}{c}\text { Responses supporting why the inequality changes direction } \\
\text { with valid mathematical explanations }\end{array}$ \\
\cline { 2 - 3 } $\begin{array}{c}\text { One of her students divides both sides of the inequality by }-1 \text { and } \\
\text { writes } x>-7 \text { for the solution. Then, another student asks why the } \\
\text { inequality changed direction. How would you respond to this } \\
\text { question? }\end{array}$ & 1 & $\begin{array}{c}\text { Responses that gave an explanation using specific values as to } \\
\text { why the inequality changes direction }\end{array}$ \\
\hline
\end{tabular}

Table 5. t-test result of the APCK scores of the PEMTs among cohorts

\begin{tabular}{|c|c|c|c|c|c|c|}
\hline Participants & $\mathbf{N}$ & Mean & SD & $t$ & df & $p$ \\
\hline First cohort & 101 & 17.89 & 5.45 & \multirow{2}{*}{-8.10} & \multirow{2}{*}{153} & \multirow{2}{*}{.00} \\
\hline Second cohort & 54 & 23.57 & 3.25 & & & \\
\hline
\end{tabular}

Table 6. t-test results of the components of APCK

\begin{tabular}{|c|c|c|c|c|c|}
\hline & & $\begin{array}{c}\text { First cohort } \\
(\mathrm{N}=101)\end{array}$ & $\begin{array}{c}\text { Second cohort } \\
(N=54)\end{array}$ & & \\
\hline & & Mean (SD) & Mean (SD) & t-value & sig \\
\hline \multirow{2}{*}{$\begin{array}{c}\text { Pedagogical } \\
\text { content knowledge }\end{array}$} & Knowledge of learner & $8.77(3.51)$ & $12.09(2.13)$ & -6.64 & 0.000 \\
\hline & Presentation of content & $11.23(3.63)$ & $15.55(3.17)$ & -7.98 & 0.000 \\
\hline \multirow{2}{*}{ Algebra content } & Algebraic expressions, equations \& inequalities & $15.26(4.44)$ & $19.00(2.71)$ & -6.47 & 0.000 \\
\hline & Functions and their properties: Linear and nonlinear & $2.79(1.81)$ & $5.11(1.53)$ & -8.38 & 0.000 \\
\hline \multirow{4}{*}{$\begin{array}{l}\text { Domains of } \\
\text { mathematical } \\
\text { knowledge }\end{array}$} & Core concepts \& procedures & $7.24(3.21)$ & $11.07(2.34)$ & -8.47 & 0.000 \\
\hline & Representations & $10.76(3.83)$ & $15.33(2.83)$ & -7.96 & 0.000 \\
\hline & Applications & $5.99(1.99)$ & $6.42(1.42)$ & -1.57 & 0.157 \\
\hline & Reasoning and proof & $3.30(1.36)$ & $4.31(1.07)$ & -5.03 & 0.000 \\
\hline
\end{tabular}

on "equal variances not assumed". Finally, in order to determine the effect of the difference created by the Algebra Teaching course, the Cohen $d$ coefficient was examined, and the ranges described by Cohen (1988) were taken into consideration for the effect size. In presenting examples from the responses of the prospective teachers, the participants were coded as PTx in order to observe ethical considerations. Finally, the data presented in the study in terms of the PEMTs' written responses were translated from Turkish into English while maintaining the essence of their meanings.

\section{RESULTS}

To assess the PEMTs' pedagogical content knowledge in the domain of algebra, a total of 28 items were administered in the test. The possible scores on these items ranged from 0 to 36 . Table 5 outlines the mean scores and standard deviations of the items, as well as the t-test results of the cohorts.

According to the t-test result, the APCK performance of the second cohort was better than that of the first cohort with a significant difference. Moreover, the Cohen's $d$ value of 1.26 indicates a large effect size. Similar procedures were carried out to determine whether this general result differed in particular in terms of algebra content and domains of mathematical knowledge in the theoretical framework illustrated in Figure 1. The $t$-test results obtained from the development of the PEMTs with respect to algebra content, domains of mathematical knowledge and pedagogical content knowledge in terms of knowledge of learner and presentation of content are shown in Table 6.

As Table 6 indicates, the scores of the PEMTs improved in terms of all components examined. Analysis showed that this increase was statistically significant in all indicators except application in domains of mathematical knowledge. The findings showing the percentages of success of PEMTs in cohorts on the basis of each component and the effect size are shown in Figure 4.

The spider web graph in Figure 4 indicates that in terms of the Cohen $d$ coefficients, the development of all indicators except the applications component of the domains of mathematical knowledge had a large impact value. In the context of percentages of gains in achievement, the component in which the PEMTs were most successful was reasoning and proof, while the component with the most improvement was functions and their properties: linear and nonlinear. When all components were considered, the applications component was the one in which the PEMTs in the first cohort performed best, while the PEMTS in the second cohort performed best in the reasoning and proof component.

When the cohorts were compared in terms of percentages of success, it can be seen that the performance of the PEMTs improved in $71 \%$ of the items (see Appendix 1). Proportionally, it is seen that the percentage of correct answers increased most on the $18^{\text {th }}$ item. In the question about how to explain the difference between equations and identities, the first cohort had a $16 \%$ success rate, and the second cohort had a $68 \%$ success rate. The $18^{\text {th }}$ item was followed by the 6 th item in terms of the success rate. However, although the improvement ratio on the $6^{\text {th }}$ item was higher in comparison to the other items, the overall performance was still found to be low. Table 7 presents the statistics for item 6 . 


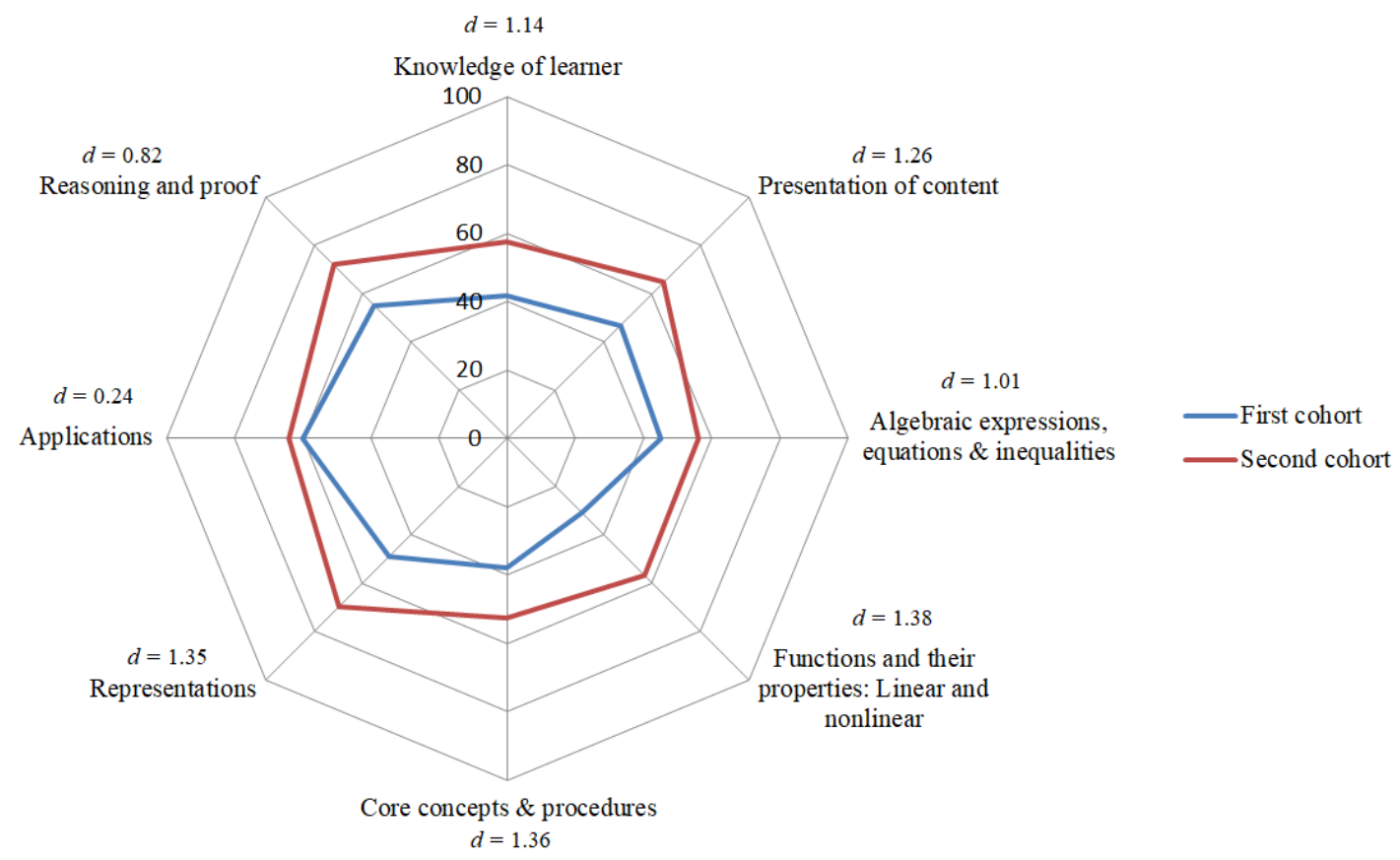

Figure 4. PEMTs performance percentages in cohorts and effect sizes

Table 7. Summary statistics of item 6

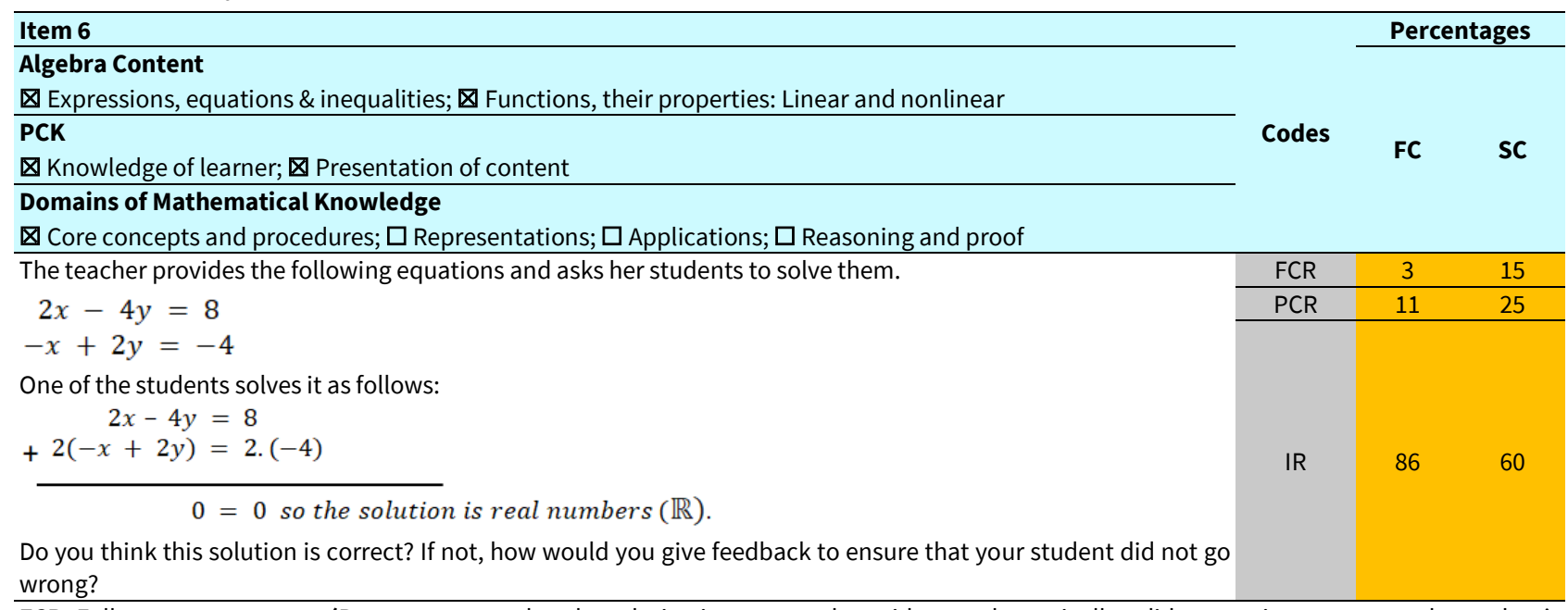

FCR: Fully correct responses (Responses state that the solution is wrong and provide a mathematically valid suggestion to support the student's understanding).

PCR: Partially correct responses (Responses indicate that the solution is incorrect but include unambiguous expressions and incomplete mathematical extrapolation).

IR: Incorrect or no response.

\section{Sample codes for FCR and PCR}

FCR of PT8 in SC: Up to $0=0$, the student's actions are correct. However, this statement does not require that the solution set be real numbers. I would ask the students if the equation applies to $x=2$ and $y=1$. From here, I would show that real numbers are not a solution. In addition, when we draw coincident lines to the Cartesian coordinate system, it can be shown that the equation is correct for certain points. So $\left(x, \frac{2 x-8}{4}\right)$ will be the elements of the solution set.

PCR of PT58 in FC: The solution is wrong, because, the first equation is the second multiplied by 2 . This equation remains and cannot be solved. FC: First cohort; $\mathbf{S C}$ : Second cohort

As Table 7 reveals, although the success rate of the PEMTs in the second cohort was higher in terms of achievement, the level they reached was not viewed as satisfactory. In this regard, $60 \%$ of the participants either answered the question incorrectly or left it blank. Another question on which the participants' performance improved was the 15th item, as summarized in Table 8.

As indicated in Table 8, the rate at which the participants presented the correct model increased from $28 \%$ in the first cohort to $69 \%$ in the second cohort. A response from a PEMT who performed the modeling correctly is exemplified in the bottom row of the table. 
Table 8. Summary statistics of item 15

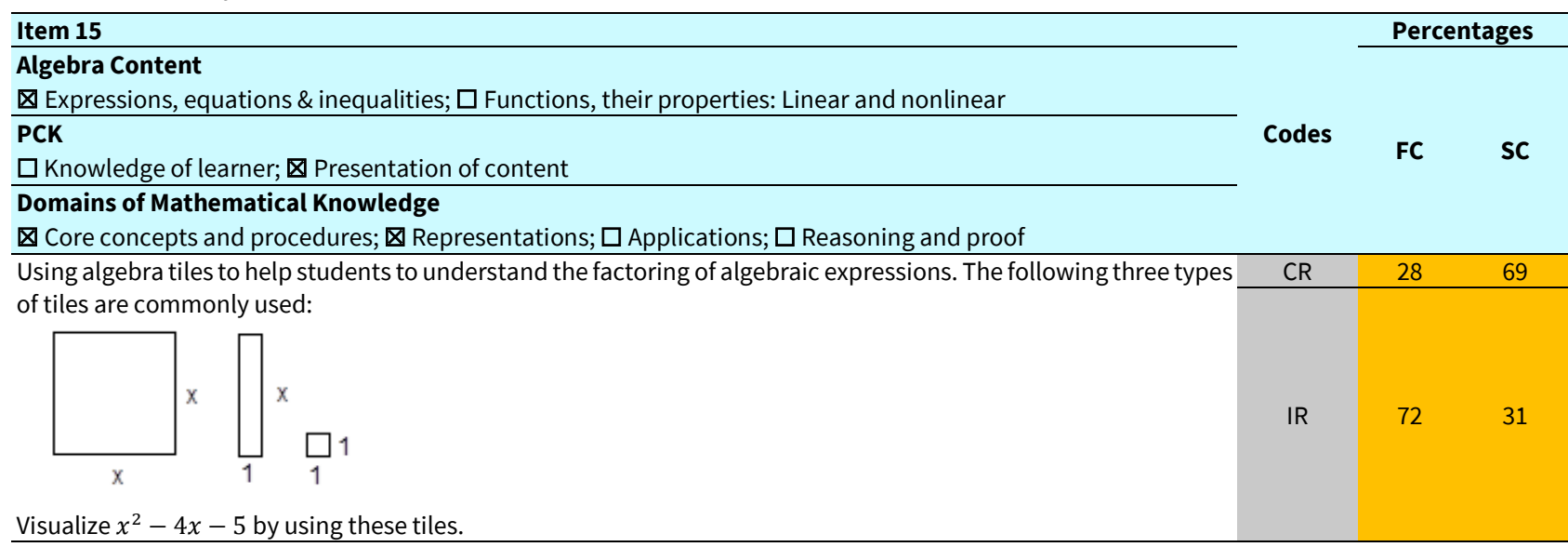

CR: Correct responses; IR: Incorrect or no response

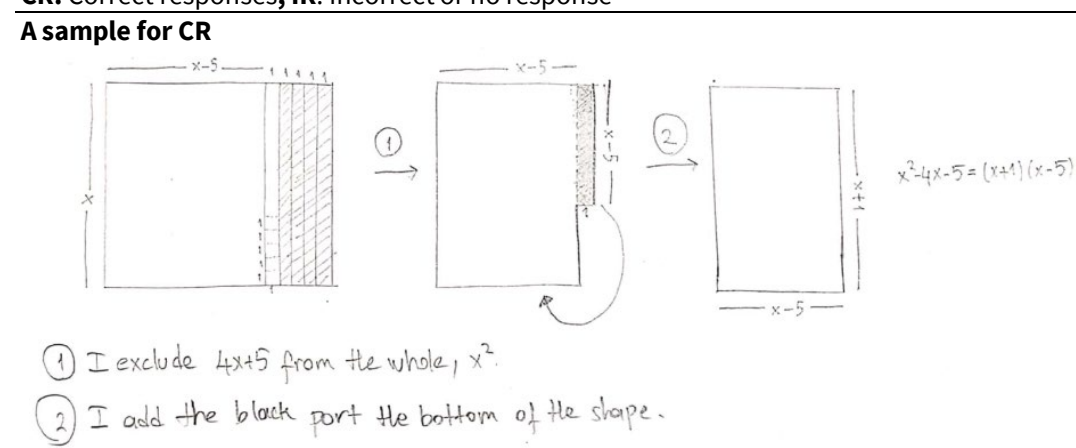

FC: First cohort; SC: Second cohort

\section{DISCUSSION AND CONCLUSION}

It is widely recognized that in order to teach mathematical knowledge, content (subject matter) knowledge alone is not sufficient; pedagogical content knowledge, which focuses on how to teach that knowledge, is also necessary (Petrou \& Goulding, 2011; Sağlam-Kaya, 2019). However, although the number of studies related to PCK has increased in recent years, most of the studies in the literature have primarily aimed to determine what teachers or future teachers know about their subject area (e.g., Leong et al., 2015; Şahin et al., 2016). To address this issue, a study by Güler and Çelik (2018) that constitutes the first phase of the present study was undertaken to examine the algebra teaching knowledge of PEMTs in terms of their CK and PCK. The results of that study revealed that the PEMTs' algebra teaching knowledge approached a moderate level, but it revealed significant deficiencies with respect to knowledge of learners and presentation of content. In order to overcome these deficiencies and to construct the content of a proposed course, a course content was created and the effect on the professional development of PEMTs was examined. The study revealed that future teachers improved in most of the components of the framework of knowledge for algebra teaching framework that was developed by Ferrini-Mundy et al. (2005) and adapted for PEMTs by Güler and Çelik (2018).

One of the components of PCK, knowledge of learners, requires awareness of students' current knowledge, in addition to understanding their mathematical thinking, understanding, difficulties and misconceptions (Baki, 2018). When the performance of the first cohort of PEMTs in the first stage of this study was examined, it was revealed that their achievement in this area averaged around $40 \%$. The data obtained from the first cohort showed that they performed poorly even with regard to basic concepts such as equations and identities (see Appendix 1, question 18). Given that researchers such as Krauss et al. (2008), and Zhang (2015) have defined CK as a prerequisite for PCK, the mathematical backgrounds of the concepts were discussed in the classroom as a means to increase the PEMTs' PCK. Afterward, some additional materials were applied. For example, responses and/or interviews with learners were distributed to the PEMTs in the form of academic articles and book chapters as a means to focus on learners' understanding. In addition, scenario-type questions were brought into the classroom, and the responses of the learners to the scenarios were discussed in terms of what they might have thought and what additional questions could be asked to inquire into their thinking. A comparison of the results of the second cohort to those of the first cohort led to the conclusion that discussions about real-life scenarios may have had a positive impact. This reflects the results of other studies indicating that professional development models enriched with reflections from real classroom environments improved PCK and knowledge of learners, in particular (Güler et al., 2020). This result also highlights the usefulness of utilizing scientific papers and publications in teacher education, as well as contributing to new studies; numerous studies related to science have concluded that reading scientific papers can help undergraduates improve scientific-process skills (Gillen, 2006; Kozeracki et al., 2006). In the present study, it was found that reading scientific papers had the potential to improve future teachers' PCKs. Moreover, as with previous studies that emphasize scenario-type questions as a means to measure PCK (Hill et al., 2004; Tatto et al., 2012), the results 
obtained from this study showed that similar scenarios are effective in the professional development of teachers, as the scenariotype questions gave the PEMTs the opportunity to focus on mathematical thinking.

In addition to the two stages of scenario-type questions (such as questioning the source of an error or misconception and presenting content to remove it) and the academic papers that served to create a discussion environment for solving student difficulties or misconceptions, various activities and concept teaching examples were presented, and discussions on the effectiveness of these examples were conducted. While the activities were critical, alternatives were also discussed. The lecturer guided these discussions and expressed his opinions about possible instructional scenarios. It can be argued that this discussion environment had two benefits. The first was related to the criticism that teacher training institutions often fail to sufficiently bridge the gap between theory and practice, as novice teachers often argue that the situations they encounter in real classrooms do not relate well with the theoretical knowledge they encountered in their undergraduate education (Sağlam-Kaya, 2019). As such, it is believed that practices such as these discussions may be effective in preparing pre-service teachers for the potential situations they may encounter in their future practice. The second benefit was that teachers had the opportunity to learn from each other through the different ideas expressed in the classroom discussion. in this regard, some of the studies in the literature on teacher education have shown that teachers are influenced by one another's practices and express preferences for methods and techniques whose effectiveness has been demonstrated (e.g., Güler et al., 2020). In this context, it can be asserted that discussing critiques and alternatives are critical in developing PCK.

Considering the domains of algebra and mathematical knowledge, it was concluded that the development of PEMTs was statistically significant in all components except applications. The applications component includes using algebra concepts and procedures to represent and interpret real-life situations. Considering the mathematical knowledge components, the course was focused slightly more on "core concepts and procedures" and "representations" than others. As stated before, the difficulties and deficiencies of the students in these components were considered in the design of the course. Although the role of real life contexts in understanding algebraic concepts and procedures was emphasized and exemplified, the students had less opportunity to examine and create these contexts in detail in the course content. Thus, students should be given more experience about examination and development of applications in future interventions.

Core concepts and procedures included topic-specific ideas and basic concepts, as well as applied algorithms and mathematical procedures (Hiebert, 2013). In this respect, although the achievement percentages of the PEMTs in the second cohort improved in comparison to those of the first cohort, it can be said that further development is needed. The same may be concluded in the domains of linear and nonlinear functions and their properties. In this context, it can be said that until the students take the algebra teaching course, they should focus on the fundamental algebraic concepts and procedures in major mathematics courses.

Major area courses make up a significant portion of the courses taught in faculties of education, in addition to courses in general pedagogy courses. Moreover, in courses such as Specialized Teaching Methods, subject matter and pedagogy are brought together, emphasizing how to teach the subject in question. In the current teacher education program, the number of courses that bring together content knowledge and pedagogical knowledge is often viewed as inadequate. However, in the teaching program to be applied with new classes in teacher education faculties in the 2021-2022 academic year, courses specific to each content domain (e.g., numbers, algebra, geometry and measurement, statistics and probability teaching) are to be included (CHE, 2018). Although this is viewed as a favorable development, the number of course hours in major area courses have been significantly reduced (CHE, 2018). Since the content knowledge cannot be considered independent of the pedagogical content knowledge, it is unclear how this arrangement will affect the knowledge types of the PEMTs who will graduate in 2022.

\section{Limitations and Educational Implications}

While interpreting the results of this study, a number of important limitations should be considered. The first and foremost of these is the gap between the years when data were collected from the cohorts. Because the revisions to the curricula applied only to newly enrolled students, the impact of the changes made to the final grades of the teaching program were observable only after four years. With this in mind, the data were collected in 2013 and 2018. Furthermore, although student quotas in education faculties have been reduced, the overall number of faculties of education has increased, leading to a corresponding increase in the number of PEMTs over the last five years. According to data from the Turkish Student Selection and Placement Center, in terms of achievement ranking, the participants in the first cohort scored higher on the university entrance exam (ÖSYM, 2020). However, despite these limitations, the implemented content was found to be more effective in developing the APCK of the lower-achieving PEMTs. As such, testing of similar designs in programs that accept students who score lower on university entrance exam (such as science education) is recommended for future research. Another limitation of the study was the focus on only two dimensions of PCK; aspects such as measurement and evaluation and curriculum knowledge were not included in the scope of the research. Future studies may be conducted with consideration for these additional dimensions. Finally, in most of the research studies, including ours, prospective teachers' PCK have been shown to improve through various interventions. However, little is known about the reflections of PCK on teaching practices and student learning in real classroom environments. Considering this gap in the literature, the reflections of PCK development as measured in paper and pencil tests can be examined by observing prospective teachers' practices throughout the internship period.

Author contributions: All authors have sufficiently contributed to the study, and agreed with the results and conclusions.

Funding: No funding source is reported for this study.

Declaration of interest: No conflict of interest is declared by authors. 


\section{REFERENCES}

Baki, A. (2018). Matematiği öğretme bilgisi [Mathematics teaching knowledge]. Pegem. https://doi.org/10.14527/9786052410318

Ball, D. L., Thames, M. H., \& Phelps, G. (2008). Content knowledge for teaching: What makes it special. Journal of Teacher Education, 59(5), 389-407. https://doi.org/10.1177/0022487108324554

Blömeke, S., Olsen, R., \& Suhl, U. (2016). Relation of student achievement to the quality of their teachers and instructional quality. In T. Nilson \& J. Gustafsson (Eds.), Teacher quality, instructional quality and student outcomes. IEA Research for Education (Vol. 2, pp. 21-50). Springer. https://doi.org/10.1007/978-3-319-41252-8_2

Blömeke, S., Suhl, U., \& Kaiser, G. (2011). Teacher education effectiveness: Quality and equity of future primary teachers' mathematics and mathematics pedagogical content knowledge. Journal of Teacher Education, 62(2), $154-171$. https://doi.org/10.1177/0022487110386798

Bütüner, S. Ö., \& Güler, M. (2017). Facing the reality: A study on TIMSS mathematics achievement of Turkey. Bayburt Eğitim Fakültesi Dergisi, 12(23), 161-184.

Çelik, D., \& Güler, M. (2018). Examination of pre-service elementary school mathematics teachers' knowledge for algebra teaching. International Online Journal of Educational Sciences, 10(1), 129-149. https://doi.org/10.15345/iojes.2018.01.011

Çelik, D., Birgin, O., Gürbüz, R., Güneş, G., Taşkın, D., Açıkyıldız, G. ... Özmen, Z. M. (2016). ilköğretim matematik öğretmeni adaylarının matematik öğretme bilgi ve inançlarının ulusal ve uluslararası düzeyde karşılaştırılması [A comparative investigation of the knowledge and beliefs of preservice elementary mathematics teachers] (TÜBITAK project with project bumber 113K805). TÜBITAK.

Cohen, J. (1988). Statistical power analysis for the behavioral sciences (2nd ed). Erlbaum.

Council of Higher Education [CHE] (2007). Öğretmen yetiştirme ve eğitim fakülteleri 1982 - 2007 (Öğretmenin üniversitede yetiştirilmesinin değerlendirilmesi) (Teacher education and education faculties 1982 - 2007 (Evaluation of teacher education at university). https://www.yok.gov.tr/Documents/Yayinlar/Yayinlarimiz/ogretmen-yetistirme-ve-egitim-fakulteleri.pdf

Council of Higher Education [CHE] (2018). Öğretmen yetiştirme lisans programları (Teacher training undergraduate programs). https://www.yok.gov.tr/kurumsal/idari-birimler/egitim-ogretim-dairesi/yeni-ogretmen-yetistirme-lisans-programlari

European Commission (2015). 2015 Avrupa yükseköğretim alanı: Bologna süreci uygulama raporu [2015 European higher education area: Bologna process implementation report]. Publications Office of the European Union.

Even, R. (1993). Subject-matter knowledge and pedagogical content knowledge: Prospective secondary teachers and the function concept. Journal for Research in Mathematics Education, 24(2), 94-116. https://doi.org/10.2307/749215

Ferrini-Mundy, J., Floden, R., McCrory, R., Burrill, G., \& Sandow, D. (2005). A conceptual framework for knowledge for teaching school algebra.

Fuller, R. A. (1996, October). Elementary teachers' pedagogical content knowledge of mathematics. Paper presented at the MidWestern Educational Research Association Conference. Chicago, IL.

George, D., \& Mallery, P. (2016). IBM SPSS statistics 23 step by step: A simple guide and reference (14th ed.). Routledge. https://doi.org/10.4324/9781315545899

Gillen, C. M. (2006). Criticism and interpretation: teaching the persuasive aspects of research articles. CBE-Life Sciences Education, 5(1), 34-38. https://doi.org/10.1187/cbe.05-08-0101

Grossman, P. \& Richert, A. (1988). Unacknowledged knowledge growth: a re-examination of the effects of the teacher education. Teaching and Teacher Education, 4(1), 53-62. https://doi.org/10.1016/0742-051X(88)90024-8

Güler, M. (2014). investigating pre-service teachers' knowledge for teaching mathematics: The sample of algebra (Unpublished Master's Thesis). Karadeniz Technical University, Turkey.

Güler, M., \& Çelik, D. (2018). Uncovering the relation between CK and PCK: An investigation of preservice elementary mathematics teachers' algebra teaching knowledge. Journal of Research in Mathematics Education, 7(2), 162-194. https://doi.org/10.4471/redimat.2018.2575

Güler, M., \& Çelik, D. (2019). How well prepared are the teachers of tomorrow? An examination of prospective mathematics teachers' pedagogical content knowledge. International Journal of Mathematical Education in Science and Technology, 50(1), 82-99. http://doi.org/10.1080/0020739x.2018.1472821

Güler, M., Çekmez, E., \& Çelik, D. (2020). Breaking with tradition: An investigation of an alternative instructional sequence designed to improve prospective teachers' noticing skills. Teaching and Teacher Education, 92, 103073. https://doi.org/10.1016/j.tate.2020.103073

Hattie, J. (2009). Visible Learning-A synthesis of over 800 meta-analyses relating to achievement. Routledge.

Hiebert, J. (2013). Conceptual and procedural knowledge: The case of mathematics. Routledge. https://doi.org/10.4324/9780203063538

Hill, H. C., Schilling, S. G., \& Ball, D.L. (2004) Developing measures of teachers' mathematics knowledge for teaching. Elementary School Journal, 105(1), 11-30. https://doi.org/10.1086/428763 
König, J., Blömeke, S., Paine, L., Schmidt, W. H., \& Hsieh, F. J. (2011). General pedagogical knowledge of future middle school teachers: On the complex ecology of teacher education in the United States, Germany, and Taiwan. Journal of Teacher Education, 62(2), 188-201. https://doi.org/10.1177/0022487110388664

Kozeracki, C. A., Carey, M. F., Colicelli, J., \& Levis-Fitzgerald, M. (2006). An intensive primary-literature-based teaching program directly benefits undergraduate science majors and facilitates their transition to doctoral programs. CBE-Life Sciences Education, 5(4), 340-347. https://doi.org/10.1187/cbe.06-02-0144

Krauss, S., Brunner, M., Kunter, M., Baumert, J., Blum, W., Neubrand, M., \& Jordan, A. (2008). Pedagogical content knowledge and content knowledge of secondary mathematics teachers. Journal of Educational Psychology, 100(3), $716-725$. https://doi.org/10.1037/0022-0663.100.3.716

Kula-Ünver, S. (2020). How do pre-service mathematics teachers respond to students' unexpected questions related to the second derivative?. Journal of Pedagogical Research, 4(3), 359-374. https://doi.org/10.33902/JPR.2020465074

Leong, K. E., Meng, C. C., Rahim, A., \& Syrene, S. (2015). Understanding Malaysian pre-service teachers mathematical content knowledge and pedagogical content knowledge. Eurasia Journal of Mathematics, Science \& Technology Education, 11(2), 363370. https://doi.org/10.12973/eurasia.2015.1346a

Manizade, A. G., \& Mason, M. M. (2011). Using Delphi methodology to design assessments of teachers' pedagogical content knowledge. Educational Studies in Mathematics, 76(2), 183-207. https://doi.org/10.1007/s10649-010-9276-z

McCrory, R., Floden, R., Ferrini-Mundy, J., Reckase, M. D., \& Senk, S. L. (2012). Knowledge of algebra for teaching: A framework of knowledge and practices. Journal for Research in Mathematics Education, 43(5), 584-615. https://doi.org/10.5951/jresematheduc.43.5.0584

National Council of Teachers of Mathematics [NCTM] (2000). Professional standards for teaching mathematics.

ÖSYM (2020). Student selection and placement system. https://www.osym.gov.tr/TR,757/arsiv.html

Park, S., Jang, J. Y., Chen, Y. C., \& Jung, J. (2011). Is pedagogical content knowledge (PCK) necessary for reformed science teaching? Evidence from an empirical study. Research in Science Education, 41(2), 245-260. https://doi.org/10.1007/s11165-009-9163-8

Petrou, M. \& Goulding, M. (2011). Conceptualizing teachers' mathematical knowledge in teaching. In Rowland T. and Ruthven K. (Eds.), Mathematical knowledge in teaching (pp. 9-25). Springer. https://doi.org/10.1007/978-90-481-9766-8_2

Sağlam-Kaya, Y. (2019). Investigation of mathematics teachers' usage frequency of learner generated examples in the classroom and its reasons. Education and Science, 44(199), 21-47. http://doi.org/10.15390/eb.2019.7877

Şahin, Ö., Gökkurt, B., \& Soylu, Y. (2016). Examining prospective mathematics teachers' pedagogical content knowledge on fractions in terms of students' mistakes. International Journal of Mathematical Education in Science and Technology, 47(4), 531551. https://doi.org/10.1080/0020739X.2015.1092178

Shaughnessy, J. J., Zechmeister, E. B., \& Zeichmeister, J. (2009). Research methods in psychology (8th Ed.). Palatino.

Shulman, L. S. (1986). Those who understand: Knowledge growth in teaching. Educational Researcher, 15(2), 4-14. https://doi.org/10.3102/0013189X015002004

Shulman, L. S. (1987). Knowledge and teaching: foundations of the new reform, Harvard Educational Review, 57(1), 1-22. https://doi.org/10.17763/haer.57.1.j463w79r56455411

Sintema, E. J., \& Marbán, J. M. (2020). Pre-service secondary teachers' mathematical pedagogical content knowledge self-concept related to their content knowledge of functions and students. International Electronic Journal of Mathematics Education, 15(3), em0598. https://doi.org/10.29333/iejme/8327

Tanışlı, D., Türkmen, H., Turgut, M., \& Köse, N. (2020). How a teacher professional development program influences students' algebra performance? Reflections from a web-based platform. Journal of Pedagogical Research, 4(3), $327-343$. https://doi.org/10.33902/JPR.2020464571

Tatto, A., Teresa, M., Schwille, J., Senk, S., Lawrence, C., Peck, R., \& Rowley, G. (2012). Policy, practice, and readiness to teach primary and secondary mathematics in 17 countries: Findings from the IEA Teacher Education and Development Study in Mathematics (TEDS-M) (pp. 1-297). International Association for the Evaluation of Educational Achievement (IEA).

Tatto, M. T., Schwille, J., Senk, S., Ingvarson, L., Peck, R., \& Rowley, G. (2008). Teacher Education and Development Study in Mathematics (TEDS-M): Conceptual framework. Teacher Education and Development International Study Center, College of Education, Michigan State University.

Taylan, R. D., \& da Ponte, J. P. (2016). Investigating pedagogical content knowledge-in-action. REDIMAT, 5(3), $212-234$. https://doi.org/10.4471/redimat.2016.2227

Usiskin, Z. (1988). Conceptions of school algebra and uses of variable. In A. F. Coxford \& A. P. Shulte (Eds.), The ideas of algebra, K12 (1988 Yearbook of the National Council of Teachers of Mathematics, pp. 8-19). NCTM.

Witzel, B. S., Mercer, C. D., \& Miller, M. D. (2003). Teaching algebra to students with learning difficulties: An investigation of an explicit instruction model. Learning Disabilities Research \& Practice, 18(2), 121-131. https://doi.org/10.1111/1540-5826.00068

Zhang, Y. (2015). Pedagogical content knowledge in early mathematics: what teachers know and how it associates with teaching and learning (Doctoral dissertation). Loyola University. 


\section{APPENDIX 1}

\section{PEMTs Performances in APCK Test Items}

\begin{tabular}{|c|c|c|c|c|}
\hline Item ID & Label & $\begin{array}{c}\text { Item } \\
\text { Format }\end{array}$ & $\begin{array}{l}\text { Percentage } \\
\text { FC }\end{array}$ & $\begin{array}{l}\text { Percentage } \\
\text { SC }\end{array}$ \\
\hline $1 \mathrm{~A}$ & Determine whether student's response is a valid proof & CMC & $87 \%$ & $93 \%$ \\
\hline $1 \mathrm{~B}$ & Determine whether student's response is a valid proof & CMC & $69 \%$ & $62 \%$ \\
\hline $1 C$ & Determine whether student's response is a valid proof & CMC & $49 \%$ & $43 \%$ \\
\hline 2 & Equation represents a pattern & $\mathrm{MC}$ & $44 \%$ & $44 \%$ \\
\hline $3 A$ & A statement representing a finite step pattern & CMC & $59 \%$ & $69 \%$ \\
\hline $3 B$ & A statement representing a finite step pattern & CMC & $78 \%$ & $74 \%$ \\
\hline $3 C$ & A statement representing a finite step pattern & CMC & $55 \%$ & $81 \%$ \\
\hline 4 & Determine a difficulty with an allocation problem & MC & $80 \%$ & $57 \%$ \\
\hline $5 A$ & Determine whether a word problem representing a given algebraic expression & CMC & $74 \%$ & $89 \%$ \\
\hline $5 \mathrm{~B}$ & Determine whether a word problem representing a given algebraic expression & $\mathrm{CMC}$ & $57 \%$ & $87 \%$ \\
\hline $5 \mathrm{C}$ & Determine whether a word problem representing a given algebraic expression & CMC & $57 \%$ & $83 \%$ \\
\hline 6 & $\begin{array}{l}\text { Analyze whether the student solution is valid and present a way to make him/her } \\
\text { understand if it is not }\end{array}$ & OE & $9 \%$ & $27 \%$ \\
\hline 7 & Analyze whether a student's thinking is valid and provide a valid response & $\mathrm{OE}$ & $29 \%$ & $44 \%$ \\
\hline $8 \mathrm{~A}$ & Determine whether a word problem represents a given equation & CMC & $76 \%$ & $24 \%$ \\
\hline $8 \mathrm{~B}$ & Determine whether a word problem represents a given equation & CMC & $87 \%$ & $93 \%$ \\
\hline $8 \mathrm{C}$ & Determine whether a word problem represents a given equation & CMC & $41 \%$ & $48 \%$ \\
\hline 9 & Provide a way to eliminate a student difficulty in exponential numbers & OE & $43 \%$ & $90 \%$ \\
\hline 10 & Provide a way to eliminate a student difficulty in changing direction in an inequality & $\mathrm{OE}$ & $25 \%$ & $43 \%$ \\
\hline 11 & Decide whether an equal-arm scale model is appropriate for a given equation & $\mathrm{OE}$ & $40 \%$ & $87 \%$ \\
\hline 12 & Analyze why one word problem is more difficult than another & $\mathrm{OE}$ & $40 \%$ & $57 \%$ \\
\hline 13 & Determine whether student explanations are valid in explaining a non-linear relationship & MC & $69 \%$ & $80 \%$ \\
\hline 14 & Determine a student difficulty about the slope in a given equation providing a justification & OE & $24 \%$ & $55 \%$ \\
\hline 15 & Modeling a factorization of an algebraic expression using algebraic tiles & $\mathrm{OE}$ & $28 \%$ & $69 \%$ \\
\hline 16 & Evaluate student solutions for finding the solution of an inequality & OE & $63 \%$ & $75 \%$ \\
\hline 17 & Analyze student responses including algebraic statements on area of a region & $\mathrm{OE}$ & $43 \%$ & $52 \%$ \\
\hline 18 & Explain the difference between equation and identity to a student & $\mathrm{OE}$ & $16 \%$ & $63 \%$ \\
\hline 19 & $\begin{array}{l}\text { Determine the students' ideas from the solution sets they have created for equation with } \\
\text { one unknown. }\end{array}$ & $\mathrm{OE}$ & $61 \%$ & $69 \%$ \\
\hline 20 & Decide whether a student solution is appropriate in an equation solution & MC & $47 \%$ & $59 \%$ \\
\hline
\end{tabular}

CMC: Complex multiple choice; MC: Multiple choice; OE: Open-ended; FC: First cohort; SC: Second cohort 